\title{
Determinants of Rural Women Economic Empowerment in Agricultural Activities: The Case of Damot Gale Woreda of Wolaita Zone, SNNPRS of Ethiopia
}

\author{
ABEBAYEHU CHAMA DIDANA \\ Lecturer, College of Business and Economics, Dilla University, Ethiopia
}

\begin{abstract}
This study was aimed at analyzing the determinants of economic empowerment of rural women through agricultural activities in the Damot Gale Woreda. A total of 369 sample farm households were randomly selected from four selected kebeles. Primary and secondary data sources were used for this study. Primary data were collected through structured questionnaire, key informant interview and focus group discussions. To this end, the author used mixed research approach. Descriptive statistics, woman empowerment in agriculture index (WEAI) and regression analysis were used to analyzing the collected data. Overall five domains of empowerment (5DE) of the study area were $74 \%$ and the $5 \mathrm{DE}$ result shows that $66 \%$ of the women in the sample were disempowered. The regression result reveals that out of fourteen explanatory variables incorporated in the model, eleven variables such as age, family size, education level, household income, off-farm income, employment/doing any paid work, ownership of property, credit utilization, distance from the market, access of information and participation of community affairs were found to be a significant determinants of economic empowerment of rural women though agricultural activities in the Woreda. Whereas factors such as spousal relationship, farm size and extension service have no significant influence. The improvement of the contribution of each indicator to women disempowerment according to their importance shall reduce disempowerment and facilitate adequate empowerment in all dimensions. Hence the findings of the study may inform policymakers about the determinants of economic empowerment though agriculture in the Woreda, and helps to formulate constructive policy that will improve economic empowerment of rural women and that will to promote the economic development of the country on the other hand.
\end{abstract}

Keywords: Economic empowerment, Binary Logistic Regression model, WEAI, Women.

DOI: $10.7176 / \mathrm{JESD} / 10-3-05$

\section{Introduction}

\subsection{Background of the study}

Women play an important role in agriculture, particularly in Africa. Moreover, Agriculture is a key driver of Ethiopia's long-term growth and food security, where the vast majority of the population of the country (approximately 84 percent) depends on it as a source of livelihood and shares substantial proportion of the total GDP of the country (CSA, 2014/15). The sector is dominated by mixed farming where crops and livestock play major roles in serving dual purposes for domestic consumption and foreign currency earnings. Agriculture contributes about $50 \%$ of the Gross Domestic Product (GDP) and $90 \%$ of the national export earnings. Although agriculture is the leading source of foreign exchange earnings, the sector is dominated by traditional subsistence and cultural perception of abundant human labor (IFPRI, 2010).

Empowering women has become a frequently quoted goal of development intervention (Mosedale, 2005). As stated by Mengistie (2013), in the economy of Ethiopia, as in many of African countries, women are the backbone of the food production system. Because, as cited in Afroz (2010) \& Chalchissa and Emnet (2013), women can prove to be a valuable resource and an asset for the country with the abilities like handling multiple tasks simultaneously, which might not be easy for male employee Standing.

\subsection{Statement of the Problem}

Since women are more than half of the total population in most of developing countries, it is very important to utilize this part of population so that the talent of whole population is optimally utilized (Afoz, 2010). Consequently, the sustainability of the economy of countries depends on the extent at which women participate in public decisionmaking and the inclusion of their needs and interests in policy which ultimately helps to ensure good governance. Studies on rural women in Ethiopia reveal that women account for 70 percent of the household food production. Their share in the total agricultural labor force is considerable where about 48 percent of the agricultural labor force is driven from female family members (MOA, 2011). So any political, economic and social activity that doesn't incorporate and benefit women cannot be fruitful because such an activity is based on less than half the manpower, half the knowledge and half the effort of that which is available in the country (WCYA, 2013).

Providing better services to rural women is not only necessary to realize their rights, but it contributes to economic growth, poverty reduction and also essential in agricultural development. Clearly, women play an 
important role in performing number of rural household farm activities but this role often goes unrecognized due to perception bias (IFAD, 2011).

Similarly, EEA and EEPRI (2006) argues that anyone who has spent just a short time in rural Ethiopia can readily observe that in most parts of the countryside women are intimately involved in all aspects of agricultural production like marketing, food procurement and household nutrition but, the view is still widely held that women do not farm. The socio-cultural perception remains strong even though numerous household farm tasks are deemed as women's work, including weeding, harvesting, preparation of storage containers, management of all aspects of home gardens and poultry rising, transporting farm inputs to and from the field, and the procurement of water for household use.

Despite being their largest share of labor, their work is not valued by the society and the decision to control over income and final product goes to the men. Not only has this, women in rural areas living in an oppressive culture that denies their right to participate in decision making on final output. Therefore, the socio-economic deprivation of women is characterized by their limited access to resources, services and employment. As a result, a large number of women are economically dependent on their spouses (Mengistie, 2013).

Even though the benefits of empowerment of rural women in agricultural activities are significant, variables associated with empowerment have not been clearly identified (Mahmud, Shah \& Becker, 2011) and according to Aregu et al. (2017) the issue of women's empowerment is a debatable as well as policy issue and not researched well in Ethiopia. In the developing countries some researchers have studied the issue of economic empowerment of rural women. For instance, Samuel (2015) in rural Kenya, Nazrul (2012) in rural Bangladesh and Ayevbuomwan et al. (2016) in rural Nigeria by using a quantitative research approach and also the level of significance of variables was not investigated statistically, except Nazrul (2012) and Ayevbuomwan et al. (2016) who statistically investigated the influence of six variables (husband's behavior, independence in spending money, independent decision making authority, involvement in family affairs, control over specific activities and position in the family) by using multiple linear regression model and six variables (age, relationship of household head, employment, gender of household head, household size, region), by using binary logistic regression model respectively, and found that they have significant influence on economic empowerment of rural women.

The current research is dissimilar from foregoing studies particularly of Nazrul, (2012) and Ayevbuomwan et al. (2016) since it was used a binary logistic regression model of Ayevbuomwan et al. (2016) and employed women empowerment in agriculture index (WEAI) to measure empowerment. In order to obtain the reliable findings the researcher determined sample size by the help of scientific formula which is more representative than that of non-probability sampling used in the above researchers. Moreover, it incorporated about fourteen explanatory variables in the model, Time gap, Methods of data analysis gap, Research approach and study area gap since there are no empirical studies that have been conducted to find the determinants of economic empowerment of rural women through agricultural activities in the Damot Gale Woreda. Consequently, this study is expected to fill such gap that has existed in the area of research for a long time by contributing some insights and implications for intervention.

Therefore, the study was carried out to address the following research questions:

$\checkmark$ What are the demographic, economic and social factors affecting the economic empowerment of rural women in agricultural activities?

$\checkmark \quad$ What is the level of women's empowerment in agriculture index in the study area?

\subsection{Objectives of the study}

The general objective of the study is to investigate the determinants of economic empowerment of rural women in agricultural activities in Damot Gale Woreda of Wolaita zone, SNNPRS of Ethiopia.

In line with above general objective, the specific objectives of the study are:

* To investigate the demographic, economic and social factors affecting economic empowerment of rural women in agricultural activities.

* To examine the level of women empowerment in agricultural index in the study area.

\section{Determinants of economic empowerment of rural women}

Some authors have tried to classify factors affecting economic empowerment of rural women in different ways; among those Ayevbuomwan (2016) applied a Binary logit model to analysis women empowerment in rural Nigeria. He classified the factors that affect empowerment of women in to into three main parts, namely 1) Individual factors (age, relationship of household head \& employment); 2) household level factors (gender of household head, household size); and 3) environmental factor (region). The division into aforementioned categories is based on the way which approached to economic empowerment from not an interdisciplinary perspective which represents a tighter outlook of determinants of economic empowerment of rural women. But in current study the researcher reclassified factors with some modification as follows: (1) Demographic factors (Age, family size, Education status of women and Spousal relationship): (2) Economic factors (Household farm income, Income from non-farm 
activities, House hold farm size, Employment/doing any paid work and Access to own property) and (3) Social factors (Utilization of Credit, Access to information channels, Contacts with Extension Agents, Participation in community affairs and Distance from market center).

\subsection{Demographic factors}

Age is one of demographic variables that affect the economic empowerment of rural women. It is as a demographic factor of women economic empowerment has been long researched by many researchers and findings are different along the different studies. It has an important role in the agricultural production process. For instance, according to research conducted by Aregu et al. (2017) employed Binary logit model to examine the impact of microfinance on woman's empowerment, the model result revealed that; age was significantly related to economic empowerment of women i.e. The age characteristics of the women has been considered as positively contributing if she is in middle age category (active youths) because she could actively engage in agricultural activities. On the other hand Taye (2014) also applied binomial logit model to analyze economic empowerment of women through micro-finance, an individual may lose the ability and energy to get involved in economic activity of production increasing practices as she gets older and older.

Operationally, family size (household size) Huria A.M (2014) employed multiple linear regression model to assess women farmers participation in agricultural extension services for income and nutrition improvement in Ethiopia: the case of Becho district, South Western Oromia. The model result showed that there is strongly positive and significant influence of household size over women empowerment. The literature shows that family size was another factor which affects economic empowerment of rural women. The larger the household size is, the more likely a woman to be empowered in rural agricultural activities. Since, family size is more related to household efforts of rural women (Jemal, 2010). Households with large family size (in the productive age group) have been reported as one of the most important contributing variable for increased agricultural production. So that it may favor the supply of labor for farm activities (Adekunle, 2013).

Education status is another important determinant factor for Economic empowerment in the lives of rural women. The literature reveals that education is a very important factor in increasing women economic empowerment on rural agricultural activities. Haimanot (2007) used binary logistic regression model to investigate the impact of micro finance on women's economic empowerment, the case of Amhara credit and saving institution (ACSI), Kobo Woreda. The model result showed that the education status of women is a basic factor that affects their economic empowerment. Similarly according to research done by Aregu et al, (2017); Vishal, (2015); and Taye, (2014), the Level of education was fundamental factor that influences to economic empowerment of women. Kishor and Subaiya (2008) argued that social development indicators such as education are significantly associated with both taking decisions alone and jointly. On individual bases, the more the rural women farmers are educated the more they tend to contact information and technology agents and become the user and participant of new agricultural practices to search for better agricultural income (Aizami, 2011).

Spousal relationship: Shahnaj P and Ingrid U, (2004) applied Multiple linear regression model to investigate empowerment of women in Bangladesh. The result of regression depicts that the spousal relationship of rural women is a basic factor that determine the empowerment of rural women. Consequently, it displays highly significant effects on economic empowerment of rural women.

\subsection{The economic factors}

Household farm size: Zhera (2014) applied Tobit model to investigate women economic empowerment through agricultural extension services the case of Meskan woreda in SNNPRS of Ethiopia. The model result demonstrates that the household farm size is direct determinant of economic empowerment of women. It was assumed that larger the farm size the farmer has, better seek to information and contact extension agent and situated to be food secure and economically strong. The empirical study conducted by Almaz (2008) shows that the larger the farm size the household has, the better participation and decision making on combination of technological packages. This means that farmers who have relatively large farm size will be more initiated to participate in different agricultural practices and to be empowered economically the reverse is true for small size farmers. Agricultural resource holdings such as land size and livestock size are supposed to positively contribute to household income (Agwu et al., 2012: Anaeto et al., 2012; Adekunle, 2013 and Rebecca, 2012). The amount of farm size 'owned' is an indicator of wealth and source of capital for agricultural production particularly where agriculture is a major source of livelihood (Adekunle, 2013).

Household income, According to Aregu et al, 2017; Taye, 2014; Haimanot, 2007 and Vishal, 2015; who applied descriptive studies to investigate on impact of microfinance services on economic Empowerment of women) the household income has statistically significant influence on economic empowerment of rural women. Damisa and Yohana (2007) argues that the annual farm income obtained from sale of crop, livestock and from sale of vegetables and other agricultural practices increases the farmers' financial capacity and increases the probability of investing and participating in new empowerment practices and technologies. 
Income from non-farm activities: given the uncertainties surrounding crop livestock production and other farm activities and inadequacy of the returns to maintain the household for the entire year, many rural households engage in undertaking diverse activities in seeking additional income from sources other than agriculture (Kaba, 2009). He has also indicated the significant influence of income towards household food security and hence reduction in poverty. Though these off/non-farm activities are diverse, in this study income sources from hand crafts, selling labor and petty trade are considered (see on variable description part). The incomes households seek from these sources are analyzed on the basis of participation in these activities and earning cash income.

Employment/doing any paid work :A study conducted in Rural Pakistan reveals that today access to supplementary non-farm source of income is a necessity rather than a luxury, because the core economic sources (farming and livestock) are not able to sustain the peasants on a stable basis (Imran and farhana, 2009). Ahmed (2013) employed a binary logistic regression model to analyze microfinance and rural women's empowerment: a cross-sectional level analysis (evidence from rural woredas of Harari region, Ethiopia). The model result demonstrates that employment/ doing any paid work is the identified determinants of women economic empowerment. Women carrying out these income generating activities always look for new income generating activities. So, they readily become empowered.

Access to own property: - Messay (2012) applied descriptive studies on the role of women in agriculture in southern nation nationalities and people's regional state: the case of Halaba special woreda, Ethiopia. He stated that women were not owners of the means of production except when they inherited out in to employment areas. Similarly Gebrat (2013) employed Binary Logit Model to analyze the determinants of women participation in micro finance and their Decision Making in Household Income; a case of Amhara credit and saving Institution (ACSI), in Sekota woreda, stated the same. Property ownership particularly Livestock is the most important asset and an index of wealth, prestige in rural community. Consequently he argues that accesses of owned property for rural women have a strongly significant influence on empowerment of women.

\subsection{The social factors}

Credit Utilization: According to Diana and Lisa (2011) rural farmers who have access to credit may overcome their financial constraints and therefore buy inputs and farm implements. That is the access to credit can relax the financial constraints of women farmers. As cited by Zhera (2014) the farmers without cash and no access to credit will find it very difficult to attain and adopt new technologies, access to inputs, and poor markets as top constraints to increasing productivity, a noteworthy gap (Ragasa, 2012). A household's access to credit has significant contribution to agricultural production (Anaeto et al., 2012 and Adekunle, 2013). Ethiopia's farmers have seasonal or irregular cash flows, uncertain harvests and in the current land-ownership construct, little to no physical collateral. Farmers' access to agro-credit (and financial services more broadly), however, remains inadequate for all farmers in general and for female farmers in particular (Rebecca, 2012).

Contacts with Extension Agents (EXTCON): The variable represents extension service as an important source of information, knowledge and advice to smallholder farmers in Ethiopia. Empirical results revealed that extension contact has a fundamental influence on farm households' adoption of new technology (Huria A.M 2014). The model result of Huria depicts that there is strongly significant and positive influence on empowerment of women. The study done by Hassan and Nhemachena (2007) find that, access to information about climate change forecasting, adaptation options and other rural agriculture activities remain important factors determining use of various climate change adaptation option for farmers in the agricultural production. Consequently, the variable, representing Development Agents contact as a source of information, has influence on farm households' uptake of agricultural technologies (Deribe et al., 2007).

Access to informational channels: Access to informational channels, for instance TV viewing, radio listening, printed materials and public meeting were considered as the important factors to provide agricultural and relevant information and informed farmers may play an important role in familiarizing women with basic information at their ease (Anila, 2009). At present, radio is the popular means of communication. Therefore, the radio ownership is assumed to increase the probability of empowerment in rural activities. A study conducted by Almaz (2008) revealed that the effort to disseminate agricultural technologies is mainly successful if there is effective dissemination of information through mass media. If information on technologies, programs, markets, etc. was more widely available and accessible; women would be better able to make their own choice out of a range of possible options.

Participation on community affairs: This variable is used to indicate the rural women's membership and involvement in different communal affairs. The study conducted by Abebe (2011) revealed that more the woman farmer was participating in communal activities, the more she will participate in the different activities of agriculture.

Distance from the market; if the main market is far away from the households' residence, they may lack information regarding the market price and quantity which makes the worse off. Hence women is nearer to the main Market towns are more likely to be empowered economically. The study conducted by Gebrat, (2013) reveals 
that the higher the demand for products and services, it is believed that the higher the economic empowerment of rural women.

\subsection{Conceptual framework of the study}

In the following figure, the relationship between dependent and independent variables is presented as follows.

\section{Fig 2.1: Conceptual frame work of the study}

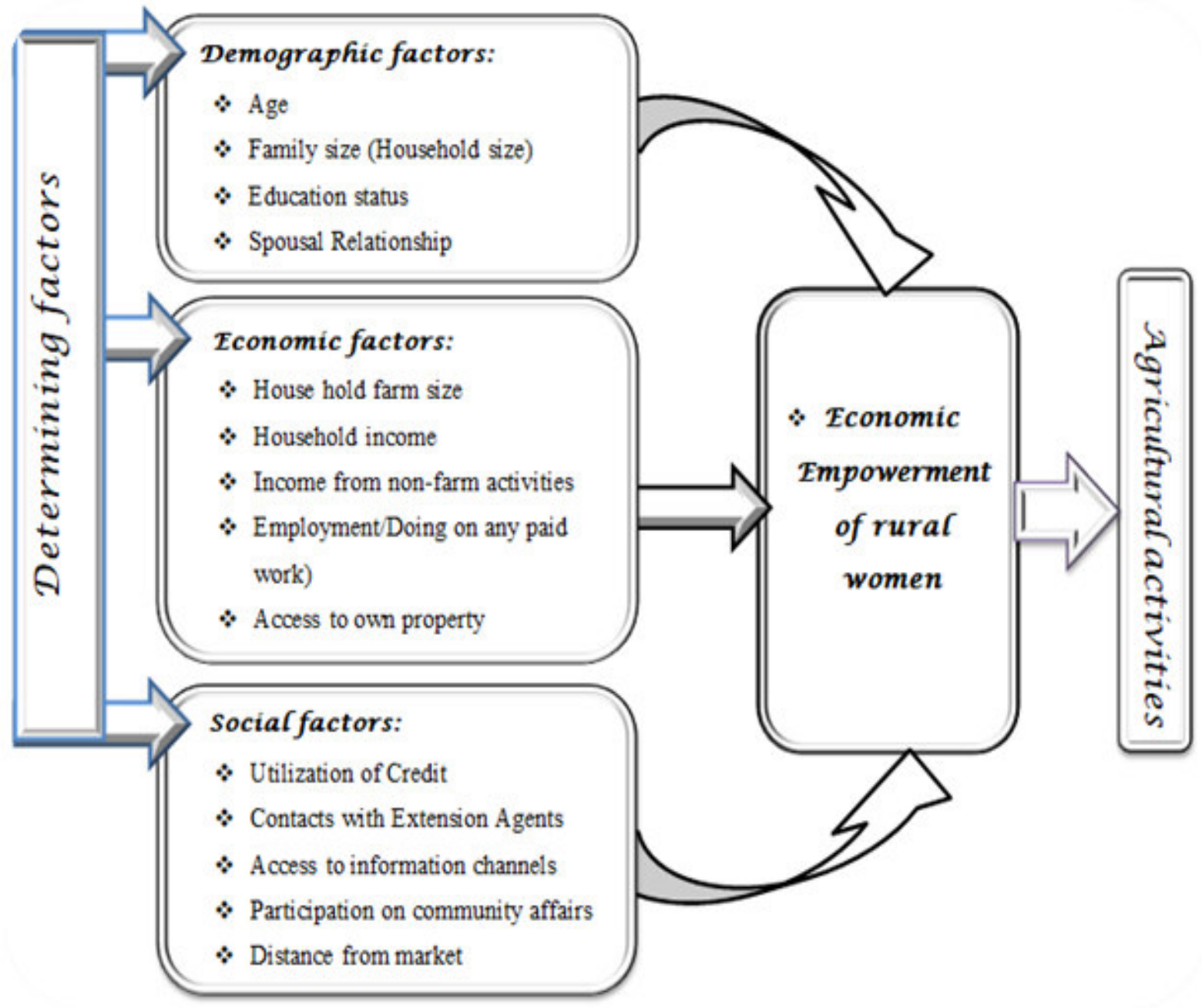

Figure: 2.1 source: own construct (2018)

NB: The variable at the middle circle (economic empowerment of rural women) is dependent variable and the other variables (demographic, economic and social factors) that listed in the rectangles surrounding at the left of the dependent variable are independent variables.

The conceptual framework in figure: 2.1 illustrate the relationship between the economic, social, and demographic characteristics of the independent variables and economic empowerment of rural women in agricultural activities (dependent variable). Therefore, in this study the researcher endeavor to analyze these relationships, identify the influence of each of independent variables on the dependent variable.

\section{Research Methodology}

\subsection{Research Approach and Designs}

The study's strategy was concerned with systematically investigating the determinants on the economic empowerment of rural women that is independent variables on the dependent one. Accordingly, so as to reach reliable and appropriate conclusion, the relevant econometric model was employed for data analysis. Moreover, both qualitative research approach so as to capture data in regard to local perception and attitude of households toward economic empowerment of rural women, as well as quantitative research approach, in order to analyze quantitative data and other basic information was employed with cross-sectional study design to achieve the objective of the study.

\subsubsection{Data Types, Sources and Methods of Data Collection}

The natures/types of data for study were both qualitative and quantitative from primary and secondary sources. In 
this study, both primary and secondary data have been collected. The collected primary data were based on the independent variables which were hypothesized to influence economic empowerment of rural women in agricultural activities in the study area.

Further the secondary data was also used to increase additional information necessary to substantiate the study. It was collected from reports, journals, articles, books, bulletins, statistical reports, and government documents, published and unpublished documents (thesis) and from web sites and records of DAs and agricultural and rural development officers of the Woreda.

\subsubsection{Sample Size and Sampling techniques}

Multi-stage sampling technique was used to select the sample. The concept of multistage sampling, since it helps the researcher to overcome problems related to geographically dispersed population where it is expensive and time consuming to construct sampling frame for large geographical area (Saunders et al., 2009). First stage, the study area Damot Gale i.e. Damot Gale was selected purposely because it is the first most populous Woreda of the Zone and the second most populous woreda next to Wonago Woreda of Gedeo Zone in SNNPRS of Ethiopia (BOFED of SNNPRS, 2017).

According to the Damot Gale Woreda finance and economic development DGFEDO (2017), first quarter report there are 27 rural Kebeles in Damot Gale Woreda. At the Second stage, the researcher was randomly selected 4 Kebeles based on their respective climate conditions (Agro-Ecological Zones). There are thirty one thousand three hundred twenty six $(31,326)$ households in rural Kebeles of the Woreda. But households of four selected Kebeles were 5,829. Then, the researcher used Yemane (1967) scientific formula, as cited by Taye (2014), by considering $5 \%$ level of error and determined sample size as follows:

$$
\begin{aligned}
& \mathrm{n}=\mathrm{N} / 1+\mathrm{N}(\alpha) 2 \\
& \quad \text { Where; } \\
& \mathrm{n}=\text { Sample Size } \\
& \mathrm{N}=\text { Total number of targeted populations }
\end{aligned}
$$

$\alpha=$ level of precision (sampling error) at $5 \%$ significance level, margin of error

Level of confidence is 95 percent; this was chosen because the convenient method reduces the possibility of nonresponse drastically.

Accordingly, sample first determined from total four Kebele households out of 27 rural Kebeles of Damot Gale Woreda by formula of Yamane as follows:

$\mathrm{n}=5829 / 1+\left(0.05^{2}\right) * 5829=374$. Consequently, 374 women of household were used as representative sample for the study and this is considered as third stage sampling.

To determine sample size from each Kebeles, the sample size determination formula of (Israel, 1992) was used.

\begin{tabular}{|c|c|c|c|c|}
\hline $\begin{array}{l}\text { Sampling site } \\
\text { (villages of each } \\
\text { Kebeles) }\end{array}$ & $\begin{array}{l}\text { Population } \\
\text { of each } \\
\text { stratum }\end{array}$ & $\begin{array}{l}\text { The formula used to } \\
\text { calculate sample size }\end{array}$ & $\begin{array}{l}\text { Calculations by } \\
\text { Applying the } \\
\text { Formula }\end{array}$ & $\begin{array}{l}\text { Proportion sample } \\
\text { size from each } \\
\text { stratum }\end{array}$ \\
\hline Wandara Gale & 1646 & $\mathrm{nh}=(\mathrm{Nh} / \mathrm{Ns}) * \mathrm{n}$ & $(1656 / 5829) * 374$ & 106 \\
\hline Ade Sibaye & 463 & $\mathrm{nh}=(\mathrm{Nh} / \mathrm{Ns})^{*} \mathrm{n}$ & $(463 / 5829) * 374$ & 30 \\
\hline Obe Jage & 1798 & $\mathrm{nh}=(\mathrm{Nh} / \mathrm{Ns})^{*} \mathrm{n}$ & $(1798 / 5829) * 374$ & 115 \\
\hline Harto Burkuto & 1922 & $\mathrm{nh}=(\mathrm{Nh} / \mathrm{Ns}) * \mathrm{n}$ & $(1922 / 5829) * 374$ & 123 \\
\hline Total & 5829 & $\mathrm{nh}=(\mathrm{Nh} / \mathrm{Ns}) * \mathrm{n}$ & $(5829 / 5829) * 374$ & 374 \\
\hline
\end{tabular}
That is $\mathrm{nh}=(\mathrm{Nh} / \mathrm{Ns})^{*} \mathrm{n}$, Where: $\mathrm{nh}=$ sample size from each stratum, $\mathrm{Nh}=$ total population in each stratum, $\mathrm{Ns}=$ Total population of the sum of strata for study and $n=$ Total sample size population from the study.

Table 3.1: Determination of sample size from each stratum by applying formula

Source: author own design (2018)

There are 106, 30, 115 and 123 rural women respondents' in Wandara Gale, Ade Sibaye, Obe Jage, and Harto Burkuto Kebeles respectively in Damot Gale Woreda. The researcher selected proportionate sample by using simple random sampling based on above formula, the sample size from each Kebeles is as fourth stage sampling provided in the Table 3.1 above.

There may be cases where there is only one woman who is up to 15 years and old aged (above 49 years) in the household selected. In cases like this, what the researcher have done is to select another woman from another household which do not fall into the sample to make up the number required i.e. it includes only with non-divorced wives, non-widowed and those within productive age of 15-59.

Consequently, to select the proportional number of households from each Kebele, population proportional to size (PPS) sampling technique was employed and systematic sampling was used to select individual households in each Kebele. Diagram Presentation is as follows 
Figure 3.1: Schematic Presentations of Sampling Procedures

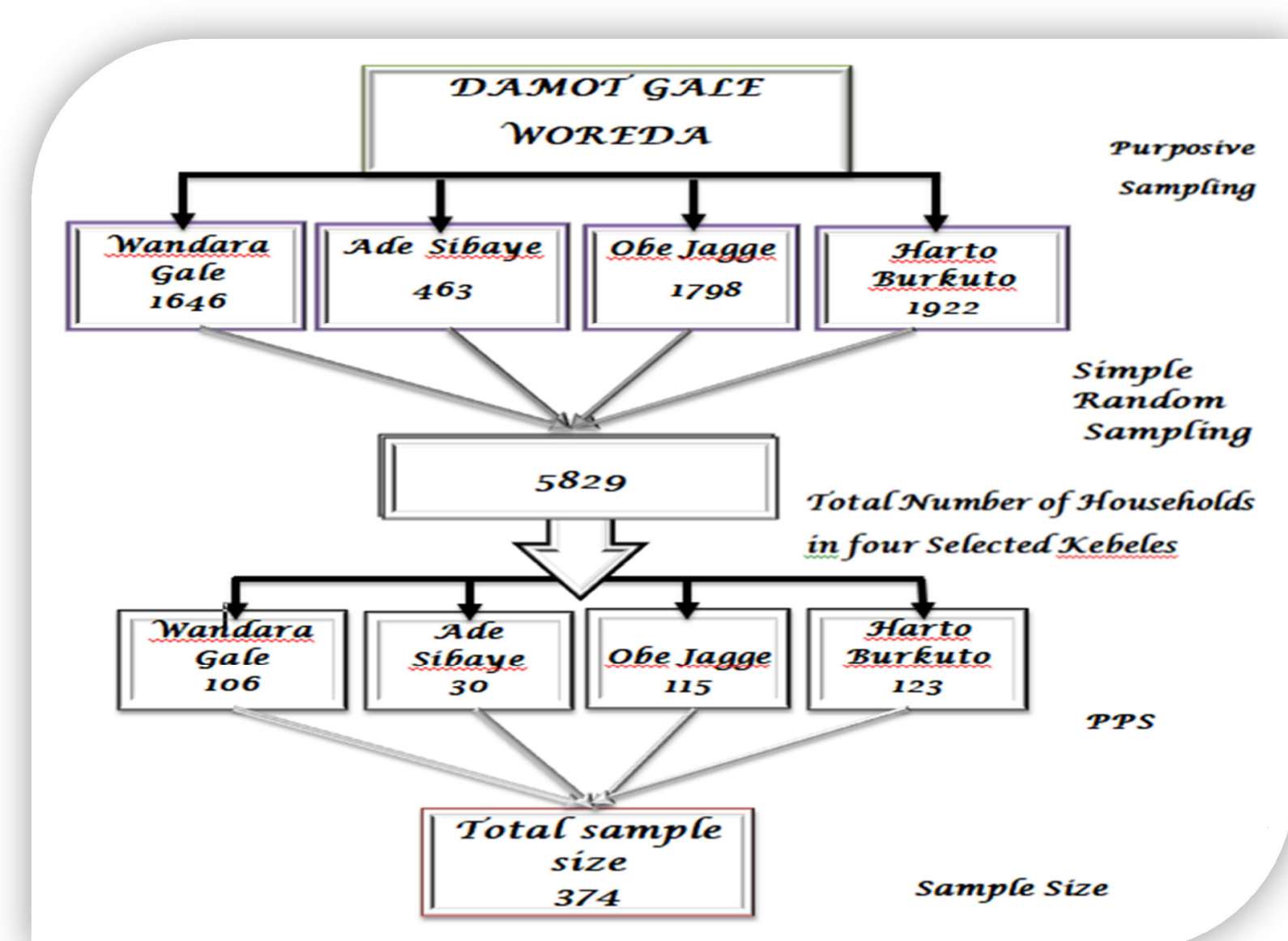

Source: Researcher's own formulation (2018)

\subsection{Model Specification}

Ayevbuomwan et al. (2016) and Julia (2010) in their study on analysis of rural women's economic empowerment in rural Nigeria and India was used logit and probit model respectively. Similarly the analysis of Microfinance and Rural Women's Empowerment in rural Woredas of Harari region by Ahmed (2013) was used logit model. They expressed the model mathematically as following by taking women's economic empowerment as dependent variable which is dummy, by making simple proxy to women empowerment and incorporating with very few explanatory variables i.e. expressed as:

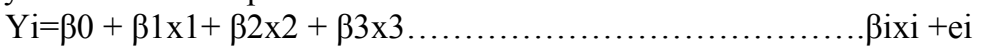

Based on the above stated model the researcher was specified the logit model that was applied in determining economic empowerment of rural women. Since the empowerment indicator, i.e., the dependent variable (economic empowerment of rural women) is dichotomous. The observable variable, women economic empowerment was measured by WEAI whether or not empowerment actually exists that is unobservable to the researcher. If the researcher state the regression equation, which is disclosed as follows:

EERWA $=F$ (AGE, FAMLYSZE, EDUSRW, DSTNCFRMKT, FARMSZE, HHFINCOM, NONFRMINCOM, EMPLYMNTPYDWRK, OWNPPTY, CRDTUTLZTN, EXTNSNSVS, ACCSINFRMTN, PCMNTYAFRS, SPSLRLNSP).

\subsubsection{Binary Logistic regression}

Once, the factors that determine economic empowerment of rural women were identified; the Binary logistic regression model was employed to show the functional form and relationship of those factors with the dependent variable.

In the studies involving qualitative factors, usually a choice has to be made between logit and probit models. According to Rajulton (2011), the logit and probit models are almost the same and choice of the model is arbitrary. Consequently, the statistical similarities between the two models make the choice between them difficult. However as pointed out by Hosmer and Lemeshow (2013), the logistic distribution (logit) has certain advantages over the others, in that the analysis of dichotomous outcome variable is externally flexible and relatively simple from 
mathematical point of view and lends itself to a meaningful interpretation. Similarly, Green (2003) argues that although both models results with similar outputs, the logit model is easier in estimation. Hence binary logit model was employed in this study to analyze the factors that determine the economic empowerment of rural women in agriculture.

Logistic regression is one of binary choice models (or dichotomous models), which is designed to model the 'choice' between two discrete alternatives. This model essentially describes the likelihood of observing success event $\left(Y_{i}=1\right)$ is directly depends on observed explanatory variables which are exogenous to the model.

The economic empowerment is dichotomies issue in its nature; whether rural women economically empowered through rural agricultural activities and otherwise. Therefore, based on the above theoretical concept, the researcher has developed the model as of Kanbiro(2018). Since, dependent variable, (i.e., economic empowerment of rural women) is a binary outcome (dichotomous) variable and treated as qualitative data, the researcher assumes one (1) for economic empowerment and zero (0) otherwise. However, the independent variables are both continuous and dummy as explained above.

Consequently, for this data logistic regression is appropriate model to measure how explanatory variables affect rural women's likelihood of being economically empowered or not. The Logit function can be derived from odds rations:

$$
\log (\text { Odds ratio })=\log \left(\frac{\text { Success }}{\text { Failure }}\right)=\log \left(\frac{y_{i}=1}{y_{i}=0}\right)=\beta_{0}+x_{i}{ }^{\prime} \beta \ldots \ldots \ldots \ldots \ldots \ldots \ldots \text { (3.1) }
$$

Where, $\mathrm{y}_{\mathrm{i}}=1$ represents an individual " $\mathrm{i}$ " is being empowered economically (success), and $\mathrm{y}_{\mathrm{i}}=0$ represents an individual "i" is being not empowered economically (failure), $\mathrm{x}_{\mathrm{i}}$ is column vector of independent variables (AGE, FAMLYSZE, EDUSRW, DSTNCFRMKT, FARMSZE, HHFINCOM, NONFRMINCOM, EMPLYMNTPYDWRK, OWNPPTY, CRDTUTLZTN, EXTENSNSVS, ACESINFRMTN, PCMNTYAFRS and SPSLRLNSP), $\beta$ is Column vector of parameters (Coefficients) to be estimated (i.e. $\beta 1, \beta 2, \beta 3, \ldots \beta 14$ ) and $\beta_{0}$ is the intercept term, Constant. Equation (3.1) shows that natural logarithmic form of odds ratio depends on observed explanatory variables.

Equation (3.1) can also be expressed in terms of probability:

$$
\log \left(\frac{P\left(y_{i}=1\right)}{P\left(y_{i}=0\right)}\right)=\log \left(\frac{P\left(y_{i}=1\right)}{1-P\left(y_{i}=1\right)}\right)=\beta_{0}+x_{i}^{\prime} \beta
$$

Where, $\mathrm{P}\left(\mathrm{y}_{\mathrm{i}}=1\right)$ is the probability of being empowered and $1-\mathrm{P}\left(\mathrm{y}_{\mathrm{i}}=1\right)$ is the probability of not empowered. The stochastic version of equation (3.2) can be formulated by adding disturbance error term:

$$
\log \left(\frac{P\left(y_{i}=1\right)}{1-P\left(y_{i}=1\right)}\right)=\beta_{0}+x_{i}^{\prime} \beta+e_{i}
$$

Where, $e_{i}$ is stochastic error term which represents all unobservable factors of empowerment, and this model shows that odds ratio is not only depends on variables incorporated in the model but also other factors which are not included in the equation. By taking exponential (antilogarithm) both side of equation (3.3) and rearranging it we have logistic function as follows:

$$
\begin{aligned}
& \frac{P\left(y_{i}=1\right)}{1-P\left(y_{i}=1\right)}=\exp ^{\left(\beta_{0}+x_{i}^{\prime} \beta+e_{i}\right)} \\
& P\left(y_{i}=1\right)=\left(1-P\left(y_{i}=1\right)\right) \exp ^{\left(\beta_{0}+x_{i}^{\prime} \beta+e_{i}\right)} \\
& P\left(y_{i}=1\right)=\frac{\exp \left(\beta_{0}+x_{i}^{\prime} \beta+e_{i}\right)}{1+\exp \left(\beta_{0}+x_{i}^{\prime} \beta+e_{i}\right)}
\end{aligned}
$$

Equation (3.4) describes that the probability of being empowered depends on observed exogenous variables. This probability is positive and limited between 0 and 1 since the underlying model follows logistic distribution. The predicted probability of being empowered therefore can be expressed as:

$$
\widehat{P}\left(y_{i}=1\right)=\frac{\exp \left(\widehat{\beta}_{0}+x_{i}^{\prime} \widehat{\beta}\right)}{1+\exp \left(\widehat{\beta}_{0}+x_{i}^{\prime} \widehat{\beta}\right)}
$$

The current model justification is different from that of Ayevbuomwan et al. (2016) and Julia (2010) for the reason that they explain it as linear regression model function even if their models were binary logistic regression.

$$
\boldsymbol{Y} i=\beta 0+\beta 1 \times 1+\beta 2 \times 2+\beta 3 \times 3
$$
Bixi $+e i$

But binary outcome (logit model) function is derived from odds ratio and explained in the above manner for the current study.

\subsection{Description of variables and their scale of measurement}

From the theoretical and empirical literature, traditional observable characteristics that may influence the probability of being economically empowered of rural women through agricultural activities are summarized with their respective unit of measurement in table below: 
Table 3.2 Summary of definitions, measurement, and hypothesis of explanatory variables

\begin{tabular}{|c|c|c|c|c|c|}
\hline Variable & Definition \& Code & Variable Type & Unit of Measurement & \multicolumn{2}{|c|}{$\begin{array}{l}\text { Expected direction } \\
\text { of influence }+/-\end{array}$} \\
\hline \multicolumn{6}{|c|}{ Dependent variable } \\
\hline $\begin{array}{l}\text { Economic } \\
\text { empowerment }\end{array}$ & $\begin{array}{l}\text { Ability and power to make } \\
\text { decision on large sale or } \\
\text { expenditures (EERW) }\end{array}$ & Dummy & $\begin{array}{l}(1=\text { Economically Empowered and } \\
0=\text { not empowered economically) } \\
\text { WEAI through } 5 \mathrm{DE}\end{array}$ & $\begin{array}{l}\text { Expected } \\
\text { sign }\end{array}$ & $\begin{array}{l}\text { Observed } \\
\text { sign }\end{array}$ \\
\hline \multicolumn{6}{|c|}{ Independent variables } \\
\hline Age & $\begin{array}{l}\text { Age of the respondent Women } \\
\text { (at the time of data } \\
\text { collection)(AGE) }\end{array}$ & Continuous & Number of years & + & + \\
\hline $\begin{array}{l}\text { Spousal } \\
\text { relationship }\end{array}$ & $\begin{array}{l}\text { Spousal relationship harmony } \\
\text { with in HHs (SPSLRLNSP) }\end{array}$ & Categorical & $\begin{array}{l}\text { Measured as moderate, good, bad } \\
\text { or else }\end{array}$ & + & + \\
\hline $\begin{array}{l}\text { Education status } \\
\text { of rural women }\end{array}$ & $\begin{array}{l}\text { Education status of rural women } \\
\text { (EDUSRW) }\end{array}$ & Continuous & $\begin{array}{l}\text { A variable measured in years of } \\
\text { schooling. }\end{array}$ & + & + \\
\hline $\begin{array}{l}\text { Family size } \\
\text { (household size) }\end{array}$ & $\begin{array}{l}\text { Members of people living } \\
\text { together, (FAMLYSZ) }\end{array}$ & Continuous & $\begin{array}{l}\text { Measured by the total family } \\
\text { members }\end{array}$ & - & - \\
\hline Farm size & $\begin{array}{ll}\begin{array}{l}\text { Household } \\
\text { size( FARMLYSZE) }\end{array} & \text { farm } \\
\end{array}$ & Continuous & $\begin{array}{l}\text { Total land owned by the house hold } \\
\text { in hectares/timad }\end{array}$ & + & + \\
\hline $\begin{array}{l}\text { House hold farm } \\
\text { Income }\end{array}$ & $\begin{array}{l}\text { House hold Farm } \\
\text { income (HHFINCOM) }\end{array}$ & Continuous & $\begin{array}{l}\text { Farm income in Ethiopian Birr } \\
\text { (ETB) }\end{array}$ & + & + \\
\hline $\begin{array}{l}\text { Income from } \\
\text { non-farm } \\
\text { activities }\end{array}$ & $\begin{array}{l}\text { Income from rural activities } \\
\text { other than agriculture } \\
\text { (NONFRMINCOM) }\end{array}$ & Dummy & $\begin{array}{l}1 \text { if Income earning from off farm } \\
\text { activities and } 0 \text { otherwise }\end{array}$ & + & + \\
\hline $\begin{array}{l}\text { Employment } \\
\text { and/or doing in } \\
\text { any paid work }\end{array}$ & $\begin{array}{l}\text { Employment/doing in any paid } \\
\text { work } \\
\text { (EMPLYMNTPYDWRK) }\end{array}$ & Dummy & $\begin{array}{l}\text { "1" if Employed/paid work, "0" } \\
\text { other wise }\end{array}$ & + & + \\
\hline $\begin{array}{l}\text { Ownership of } \\
\text { property }\end{array}$ & $\begin{array}{l}\text { Having own } \\
\text { property(OWNPPTY) }\end{array}$ & Dummy & 1 if have owned, and 0 otherwise & + & + \\
\hline Credit & $\begin{array}{ll}\text { Credit } & \text { utilization } \\
(\text { CRDTUTLZTN) } & \end{array}$ & Dummy & $\begin{array}{l}\text { Taking a value of } 1 \text {, if the woman } \\
\text { utilize credit in the study period } \\
\text { and } 0 \text {, otherwise }\end{array}$ & + & + \\
\hline $\begin{array}{l}\text { Extension } \\
\text { services }\end{array}$ & $\begin{array}{l}\text { Contact with extension agents } \\
\text { (EXTNSNSVS) }\end{array}$ & Dummy & $\begin{array}{l}\text { Contact with extension agents } \\
(=1, \text { if yes; }=0, \text { otherwise }) \text {. }\end{array}$ & + & - \\
\hline $\begin{array}{l}\text { Information } \\
\text { channels }\end{array}$ & $\begin{array}{l}\text { Access to information channels } \\
\text { (ACSINFRMTN) }\end{array}$ & Dummy & $(=1$, if yes $;=0$ otherwise $)$ & + & + \\
\hline $\begin{array}{l}\text { Participation on } \\
\text { community } \\
\text { affairs }\end{array}$ & $\begin{array}{l}\text { Participation in community } \\
\text { affairs (PCMNTYAFFRS) }\end{array}$ & Continuous & $\begin{array}{l}\text { Participation in Community } \\
\text { affairs, Measured by Likert five } \\
\text { point scales: make decision about } \\
\text { myself. 1=strongly disagree to } \\
5=\text { strongly agree. }\end{array}$ & + & + \\
\hline $\begin{array}{l}\text { Distance from } \\
\text { market }\end{array}$ & $\begin{array}{l}\text { Distance of the respondents } \\
\text { from home to the market. } \\
\text { (DSTNCFRMMKT) }\end{array}$ & Continuous & $\begin{array}{l}\text { Distance from market center in } \\
\mathrm{Kms}\end{array}$ & - & - \\
\hline
\end{tabular}

\subsection{Methods of data Analysis}

After accomplishment of data collection procedure, it should have classified as per each variable, the qualitative data was coded to be measured quantitatively. In this research data were analyzed by inferential statistics (logistic regression) by the help of Stata Software package version 13.0 in order to get the reliable finding. Women empowerment in agricultural index (WEAI) was used to analyze women empowerment; the five dimension of empowerment with ten indicators was used and weighted according to their weight (Alkire et al., 2012:33) the 5DE contribute to the $90 \%$ of the measurement. According to (Alkire et al, 2012:33) to be empowered one has to achieve adequacy in more than $80 \%$ of the indicators. A cut off point for analysis is any combination of number between 0 and 100\% following the international standard set by Alkire et al, 2012:33 cutoff point at 20\% was used.

\section{Results and Discussion}

A total number of 374 questionnaires were administered and distributed to rural women, of which 369 filled completely and returned. This made the return rate around $98.6 \%$, indicates very good response rate. After the data were collected, checked for errors and completeness; this study employed WEAI and binary logistic regression for data analysis.

\subsection{Computing the women empowerment in agriculture index}

The Women Empowerment in Agriculture Index (WEAI) is the first-ever measure to directly capture women's empowerment and inclusion levels in the agricultural sector, Mayson (2015). In this case, this innovative tool 
tracks women's engagement in agriculture in five domains: production, resources, income, leadership and time use, and they comprise ten indicators.

Table: 4.2, presents the overall disempowerment score for the sample and which presents the breakdown of the disempowerment score by domains and indicators. The WEAI for the study area is the result of weighted 5DE i.e. 0.739 (the value of 5DE, five dimensions of empowerment was 0.739). This result is higher than those cited in the literature for a number of other areas like Meskan Woreda of SNNPRS of Ethiopia Zhera (2014), but lower than that of lemlem, A. et.al, (2016) at Toke Kutaye District of Oromia, Ethiopia. The 5DE result in Table 4.1 showed that, overall, 66 percent of the women in the sample were disempowered. This also indicated that 34 percent of women were empowered. Therefore 5DE for Damot Gale Woreda shows that the empowered headcount ratio is 34.42 percent $(1-\mathrm{H})$ among rural women. The inadequacy achievement of the disempowered women was 39.72 percent. This implies that the disempowered woman had inadequacy in $40 \%$ of the indicators or they had achieved adequacy in $60 \%$ of the 5DE indicators.

To identify the areas that contribute most to women's disempowerment, the women's disempowerment index (M0) by domain and indicator computed. Therefore, women's disempowerment index which is the result of the product of disempowerment headcount ratio and average inadequacy score is $26 \%$ and the 5DE is (1-M0) which is $74 \%$. The WEAI for the sample areas in Damot Gale Woreda is 0.7396 . It is a weighted average of the 5DE Table: 4.2 .

Table 4.1 The WEAI of Damot Gale Woreda.

\begin{tabular}{|c|c|}
\hline \multicolumn{2}{|c|}{ Respondents } \\
\hline Indexes & Rural Women \\
\hline Disempowered Headcount $(\mathrm{H})$ & $65.58 \%$ \\
\hline Empowered Head Count (1-H) & $34.42 \%$ \\
\hline Average inadequacy score (A) & $39.72 \%$ \\
\hline 5DE Index Mo $=(\mathrm{AxH})$ & 0.2604 \\
\hline 5DE Index (1-Mo) & 0.7396 \\
\hline No of observations used & 369 \\
\hline Total observations & 369 \\
\hline$\%$ Data Used & 100 \\
\hline
\end{tabular}

Source: Author's calculations (2018).

Note: $\mathrm{WEAI}=$ Women's Empowerment in Agriculture Index; 5DE = five domains of empowerment.

The decomposition of Damot Gale Woreda 5DE (see Table:4.2) shows that the domains that contribute most to rural women's disempowerment shows that About 27.64 percent of rural women made decision in production and 92.41 percent lack sole decision-making power over production. The results indicate rural married women get less empowerment effects which may bring, for instance, through renewed stimulus to small scale agriculture, may not reach rural women directly, due to their lack of command over productive resources and control over output, as well as, lack of time. Similarly, 82.11 percent of women lack control over the use of income.

The findings also reveal that about 67.21 and 55.83 percent of rural women lack access to credit as well as own resources and the ability to make decisions about it. These results to the constraints facing in terms of facing additional restraints which prevent them from gaining the full benefits from the land they cultivate. They are highly dependent on others, particularly on husbands, male relatives or share cropping partners for their labor, skills and inputs, since they are, by convention, unable to plough, sow, harvest and store on their own without support from their relatives. They usually make decisions to adopt new technologies or practices after consulting their male relatives.

The study result also revealed that the 16.26 percent women have little decision-making power over the purchase, sale, or transfer of assets. Consequently, the study had to increase the understanding of the different roles of women in agricultural activities, marketing and decision-making, and their share in the benefits; to identify potential barriers for women's empowerment in market-led development initiatives; and to identify what actions may overcome some of these barriers. 
Table: 4.2. Computing the rural women empowerment in each domain in agriculture

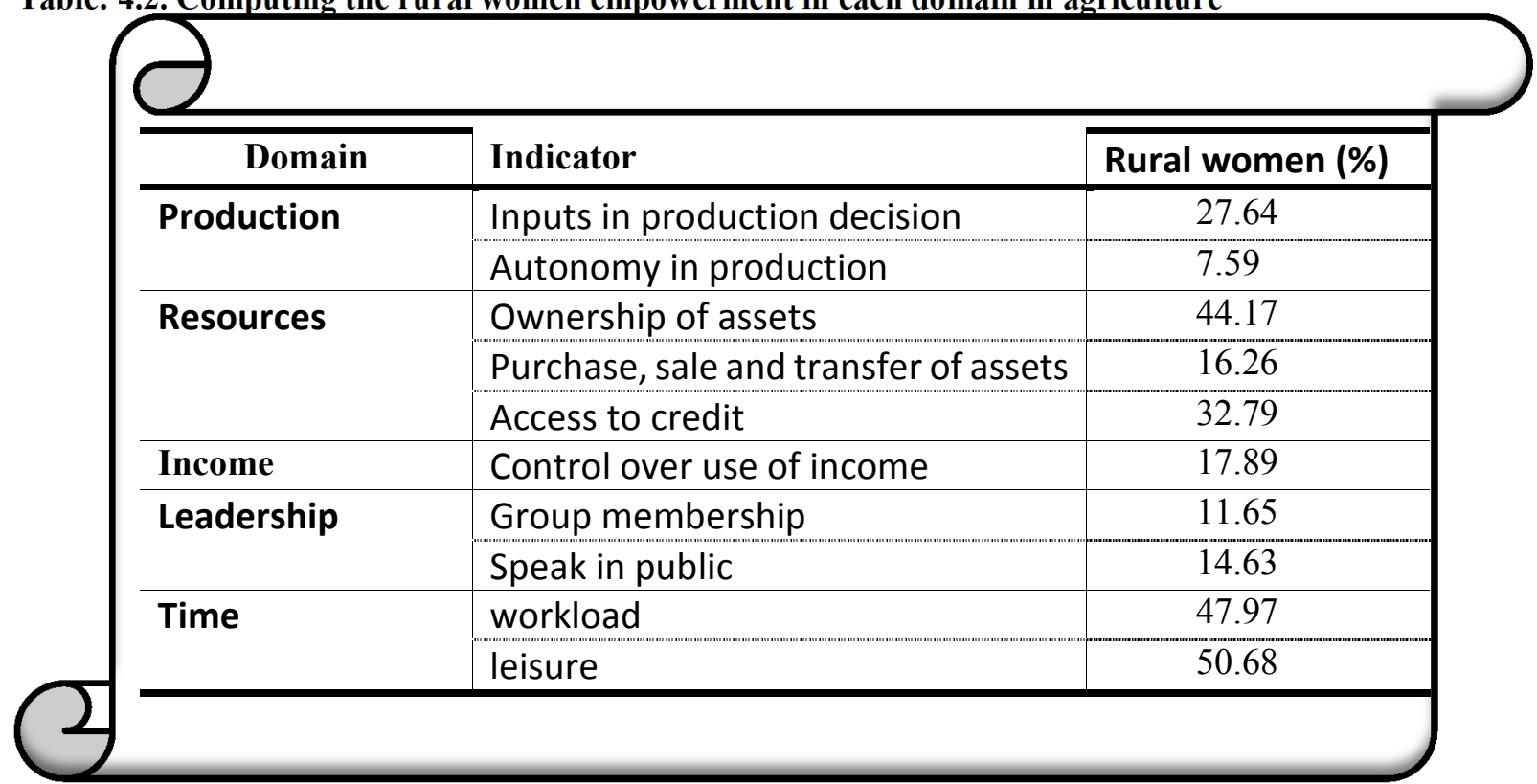

Source: Author calculations (2018)

The finding shows that 88.35 percent of these rural women are not group members and only 14.63 women of the study population responded as they have got opportunity to public speech and ability to make speech in public. In the other way observed in Group membership and speech in public were linked to constraints to women's ability or willingness to increase the leadership position, or market-increased production, including gender biases in social service systems.

Accordingly, 47.97 percent of rural women had domestic and productive work load which is time consuming above 11 hour per day and 49.42 percent of rural women do not have enough leisure time. This result depicts that there was disparity between workloads and share in input production decision, and there was a very real risk that process of productivity may further marginalize rural women.

\subsection{Results of logit model on determinants of rural women Economic empowerment}

The model result indicates that out of 14 explanatory variables which were considered in the econometric model, 11 variables were found to significantly influence the probability of being economically empowered in rural agricultural activities. These are age of respondents (AGE), family size (FAMLYSZE), educational status of rural women (EDUWR), household farm income (HHFINCM), off/non-farm income of household (NNFRMINCMHH), employment/doing any paid work (EMPLYMNTPYWRK), owning property (OWNPPTY), credit utilization (CRDTUTLZTN), access to information (ACCSSINFRMTN), participating on community affairs (PCMNTYAFFRS) and distance from the market (DSTNCFRMKT) Whereas the remaining three explanatory variables were found to have no statistically significant influence on economic empowerment of rural women in the study area. These variables include; Spousal relationship (SPSLRLNSP), farm size (FARMSZE) and extension Services (EXTNSNSVS) are not statistically significant for economic empowerment of rural women in the study area. 
Table 4.3. Regression result: dependent variable (EERWA) through Stata Version 13.0

\begin{tabular}{|c|c|c|c|c|c|}
\hline \multicolumn{3}{|c|}{ Log likelihood $=-117.18191$ ( $\log$ of probability of success). } & \multicolumn{3}{|c|}{$\begin{array}{ll}\text { Number of Obs } & =369 \\
\text { LR chi2 }(14) & =273.05 \\
\text { Prob }>\text { chi2 } & =0.0000 \\
\text { Pseudo R2 } & =0.5381\end{array}$} \\
\hline Variable & Coefficient. & Std. Err. & $\mathrm{Z}$ & $\mathrm{P}$-value & Marginal effect \\
\hline AGE & $0.464 * * *$ & 0.181 & 2.56 & 0.010 & 0.113 \\
\hline FAMILY SIZE & $-0.624 * * *$ & 0.188 & -3.31 & 0.001 & -0.154 \\
\hline EDUCATION LEVEL & $0.346^{* *}$ & 0.136 & 2.55 & 0.011 & 0.085 \\
\hline DISTANCE FROM MARMKET & $-0.396^{*}$ & 0.22 & -1.78 & 0.076 & -0.098 \\
\hline FARM SIZE & 0.056 & 0.223 & 0.23 & 0.818 & 0.014 \\
\hline HOUSE HOLD INCOME & $1.748 * * *$ & 0.245 & 7.39 & 0.000 & 0.430 \\
\hline NON-FARM INCOME & $1.242 * * *$ & 0.436 & 2.85 & 0.004 & 0.290 \\
\hline EMPLOYMENT PAID WORK & $-1.183 * * *$ & 0.393 & -3.01 & 0.003 & -0.286 \\
\hline OWNERSHP PROPERTY & $1.385 * * *$ & 0.385 & 3.59 & 0.000 & 0.333 \\
\hline CREDIT UTLIZATION & $-2.889 * * *$ & 0.58 & -4.95 & 0.000 & -0.579 \\
\hline EXTENSION SERVICES & -0.458 & 0.395 & -1.15 & 0.249 & -0.113 \\
\hline ACCESS INFORMATION & $2.427 * * *$ & 0.565 & 4.30 & 0.000 & 0.537 \\
\hline COMMUNITY AFFAIRS & $1.052 * * *$ & 0.251 & 4.20 & 0.000 & 0.259 \\
\hline SPOUSAL RELATIONSHIP & 0.233 & 0.228 & 1.02 & 0.308 & 0.057 \\
\hline CONS & -9.001 & 1.579 & -5.70 & 0.000 & \\
\hline
\end{tabular}

Note: $-* * * * *$ and $*$ are represents of statistically significance at $1 \%, 5 \%$ and $10 \%$ level of significance, respectively.

Source: own survey (2018)

Fitted model in equation form can be expressed as follow: $\widehat{\boldsymbol{P}}\left(\boldsymbol{y}_{\boldsymbol{i}}=\mathbf{1}\right)=\frac{\exp \left(\widehat{\boldsymbol{\beta}}_{\mathbf{0}}+\boldsymbol{x}_{\boldsymbol{i}}^{\prime} \widehat{\boldsymbol{\beta}}\right)}{\mathbf{1}+\exp \left(\widehat{\boldsymbol{\beta}}_{0}+\boldsymbol{x}_{\boldsymbol{i}}^{\prime} \widehat{\boldsymbol{\beta}}\right)}$

$$
\begin{aligned}
& \exp (-9.00+0.464 A G E+0.624 F A M L Y S I Z E+0.347 E \text { DUSRWA } \\
& -0.396 \text { DST NCFRMKT + 0.0564FRMSZE + 1.748HHFINCM } \\
& \text { +1.242NONFRMINCM - 1.183MPLYMNTPYDWRK + 1.385OWNPPTY } \\
& -2.890 \text { CRDTUTLZTN - 0.458EXTNSNSVS + 2.427ACSINFRMTN } \\
& \widehat{P}\left(y_{i}=1\right)=\frac{+1.051 P C M N T Y A F R S+0.233 S P S L R L N)}{1+\exp (-9.00+0.464 A G E+0.624 F A M L Y S I Z E+0.347 E D U S R W A} \\
& -0.396 \text { DST NCFRMKT + 0.056FARMSIZE + 1.748HHFINCOM } \\
& \text { +1.242NONFARMINCM - 1.183EMPLYMNTPYDWRK + 1.385OWNPPTY } \\
& -2.890 \text { CRDTUTLZTN - 0.458EXTNSNSVS + 2.427ACSINFRMTN } \\
& +1.051 \text { PCMNTYAFRS + 0.233SPSLRLSP) }
\end{aligned}
$$

Where: - $\hat{P}\left(y_{i}=1\right)$ is the estimated probability of being economically empowered.

$\exp =$ exponent and variables written in bold are independent variables.

As it can be seen from Table: 4.3 the likelihood ratio chi-square have value of 273.05 with its p- value of 0.000 this implies that the fourteen independent variables i.e. (age of respondents (AGE), educational status of rural respondents (EDUSRW), family size (FAMLYSZE), distance from the market (DSTNCFRMMKT), household farm income (HHFINCM), non/off-farm income of household (NONFRMINCM), employment/doing any paid work (EMPLYMNTPYDWRK), owning property(OWNPPTY), credit utilization (CRDTUTLZTN), access to information (ACCSSINFRMTN), participating on community affairs (PCMNTYAFFRS), farm size (FARMSZE), extension Services (EXTNSNSVS) and spousal relationship (SPSLRLN) incorporated in the model were jointly statistically significant on economic empowerment of rural women i.e., the model as whole is statistically significant.

Pseudo R-square with value $(\mathrm{R} 2=0.5381)$ shows that about 53.81 percent of change on economic empowerment of rural women is explained by independent variables incorporated with in the model i.e. As indicated in the above table, the pseudo R2 value of the model used to measures to what extent the independent variables explained the dependent variable is $53.8 \%$. This implies that $53.8 \%$ of the variation in women economic empowerment is explained by the aforementioned explanatory variables i.e. the variables collectively explains 53.8 of changes in women's empowerment. Thus, these variables collectively are good explanatory power. While, the remaining less than half percentage i.e. $46.2 \%$ variation in economic empowerment of rural women in the study area could be explained by exogenous variables which are outside the model. 
The Table: 4.3 above shows that, the researcher tested whether the fourteen explanatory variables incorporated in the study affect the economic empowerment of respondents in agricultural activities. Out of which, eleven variables such as age of respondents, family size, educational status, household farm income, non/off-farm income, employment/doing any paid work, owning property, credit utilization, access to information, distance from the market center and participation on community affairs were statistically significant.

\subsubsection{Explanation of significant explanatory variables}

In light of the above summarized model results, possible explanations for each significant explanatory variable are given successively as follows:

Age of the respondents (AGE): The literature has also found effects of age of household members and individual characteristics on empowerment. As expected, age of the respondents was hypothesized that, it will have a positive relationship with the dependent variable. The result of the Binary logit regression model has shown that, age has positive influence on dependent variable with $\left({ }_{\beta}=0.464\right)$ and statistically significant at $1 \%$ level. This finding is consistent with results of studies done by [Gebrat (2013); Ahamed (2013); Kaba (2009); Roman (2010) and Ayevbuowan et al (2016)]. But the result of this finding is inconsistent with the studies of Mengistie (2014); Aregu et.al (2017); Desalegn (2008) and Zhera (2014) which illustrates that age is negatively and significantly influences the economic empowerment of women in agricultural activities.

The marginal effect of the model also reveals that, as the age of respondents increase by one year on average the probability of women to become economically empowered increase by $11 \%$ of marginal effect, citrus paribus. Therefore, the researcher can conclude that, as the age of women increases, the probability of being economically empowered will also increases in Damot Gale Woreda.

Family size (FAMILSIZE):-. Family size has been hypothesized to have a negative relationship with women Economic empowerment through agricultural activities. It is obvious that the more increase in the household size the narrower opportunity to be empowered economically the house hold members. Therefore, the more family size to a household means the more being not empowered economically. The regression result has shown that, family size has negative influence on dependent variable with $\left.{ }_{\beta}=-0.624\right)$ and statistically significant at $1 \%$. This study is consistent with the findings of Amanuel et.al (2016) and Mariam et.al (2014). The marginal effect of the model showed that, as number of household size of women increases by additional one year on average, the probability of women to become economically empowered decreases by $15 \%$ marginal change.

Educational status of rural women (EDSRW): It is obvious that education increases the knowledge and skill of the peoples in a society. Therefore, the more education to a society means the more intervention in different economic activity by that society. Consequently, Education has been hypothesized to have a positive relationship with women Economic empowerment through agricultural activities. The Binary logit regression result has shown that, Education status has positive influence on dependent variable with $(\beta=0.346)$ and statistically significant at $5 \%$ level.

The result of this study on relation between educational level and women economic empowerment were consistent with the findings of Amanuel et.al (2016); Alkireet al (2012); Aregu et al, (2017); Mariam et.al, (2014) and Margaret (2015) that their study depicts that the relationship between economic empowerment and education was significantly related. But the result of this finding is not consistent with the results of Ahmed, (2013) and Zhera, (2014) which illustrates that there is no definite conclusion can be drawn about the relationship between education and economic empowerment of women. The association is insignificant as well. However, the proportion of empowered women in the literate sample increases with education.

The marginal effect of the model showed that, as number of years of schooling of women increases by additional one year on average, the probability of women to become economically empowered increases by $8.5 \%$ marginal change, keeping other things constant. The model output also reveals that education is positively and significantly related with the dependent variable at $1 \%$ probability level.

No definite conclusion can be drawn about the relationship between spousal relation and economic empowerment of rural women in the Damot Gale Woreda, and the association is insignificant as well. However, the proportion of economically empowered women in the sample decreases with having bad spousal relationship. The association is insignificant nonetheless.

Similarly, there is no definite conclusion can be drawn about the relationship between farm size and economic empowerment in the study area and the association is insignificant as well. However, the proportion of economically empowered women in the sample increases with having large hectares of land. The association is insignificant nonetheless.

Household farm income (HHFINCM): Respondents are getting their incomes from different crop and livestock income sources and other rural agricultural activities. Income is one of the basic factors for the people to increase their economic empowerment in different development activities. If respondents have more agricultural income, then they will purchase different farm inputs and implements as well and will get more profit/product from agriculture. Therefore, this variable has been hypothesized to have a positive and significant relationship with the dependent variable. The model output also supports the hypothesis and shows that farm income has affected the 
economic empowerment of women in rural agricultural activities positively and significantly at $1 \%$ probability level.

The result of the model has shown that, household farm income has positive influence on dependent variable with $(\beta=1.748)$ and statistically significant at $1 \%$. This is may be due to, women whose household is having more income have more power in bargaining in the household, have the ability to take part more freely in the economic sphere, and have more mobile in the communities. The finding of this study is consistent with results of studies done by [Desalegn (2008); Imran et.al, (2009); Aregu et al (2017); Gebrat (2013); Mariam et.al (2014); Asres (2005) and Mengistie (2013)].

The marginal effect of the model showed that, as income of household increases by additional one birr on average the probability of rural women to become economically empowered increases by $43 \%$ marginal change, ceterus paribus.

The income from off/non-farm (INCOMFNM): The result of the Binary logit regression model has shown that, non-farm income has positive influence over the dependent variable with $\left.{ }_{\beta}=1.242\right)$ and statistically significant at $1 \%$. This finding is consistent with results of studies done by Aregu et al (2017) and Zhera (2014) but not consistent with that of Gebrat (2013)]. The marginal effect of the model result reveals that women who have a non/off farm income are more likely to be economically empowered than women haven't non-farm income by $29 \%$ keeping other things constant. The result corresponds with the prior expectation.

With regarding to Employment and/or doing in any paid work of the respondents as one of factor that affect economic empowerment of rural women in agricultural activities. Since the regression result shows that the coefficient of not employed/doing any paid work is a dummy, It is negative and statistically significant at $1 \%$ level $(\beta=-1.183)$ and because, $(p$-value $=0.003)$ is less than $1 \%$ significance.

The marginal effect of the model result reveals that not employed/ doing any paid work women are less likely to be economically empowered than employed/ doing any paid work women by $29 \%$. This indicates the probability of being economically empowered for unemployed/not doing any paid work is less than that of employed/doing any paid work i.e. women who were employed/ doing any paid work found to have more economically empowered than unemployed/ not doing any paid work.

The result of this study is consistent with finding of other studies done by Amanuel (2016); Margaret (2015) and Ayevbuomwan et al (2016), but inconsistent with the result of Ahmed (2013). According to Ahmed, paid work is insignificant in affecting women's empowerment. Consequently, Unemployed/not doing any paid work women have less probability to be economically empowered than employed Women. Therefore, the hypothesis that stated as employed/ doing any paid work women has more economically empowered than unemployed/ not doing any paid work is accepted.

Own property (OWNPPTY): As expected, this variable was positively associated with economic empowerment of rural women with $(\beta=1.385)$ and statistically significant at $1 \%$. The marginal effect of the model result reveals that women having own property are more likely to be empowered than those who haven't own any property by $33 \%$. This result is consistent with finding of other studies like, Margaret (2015); Gebrat (2013) and Mariam et.al (2014)

With regarding to Credit utilization of the respondents as one of factor that affect economic empowerment of rural women in agricultural activities, the logit regression result depicts that the coefficient of non-credit utilizers dummy is negative and statistically significant with $(\beta=-2.889)$ and statistically significant at $1 \%$.

The marginal effect of the model result reveals that non-credit Utilizer women are less likely to be economically empowered than utilizers of credit women by $58 \%$. This indicates the probability of having economically empowered for non-credit utilizers is less than that of utilizers of credit. This result is consistent with finding of other studies conducted by Margaret (2015) and Mengistie (2013) but inconsistent with the result of Zhera (2014). Therefore, the hypothesis that stated as credit utilizer women has more economically empowered than noncredit utilizers is accepted.

No definite conclusion can be drawn about the relationship between Extension services and economic empowerment of rural women in the Damot Gale Woreda and the association is insignificant as well. However, the proportion of economically empowered women in the sample increases with having access of extension services. The association is insignificant nonetheless.

Access to Information (ACCSSINFRMTN): As expected, this variable was positively associated with economic empowerment of rural women and statistically significant at $1 \%$ probability level. Mass media play an important role in transferring information in relatively shorter time and can cover a large area at the same time. Individuals who have access to mass media are economically empowered as they are aware about their legal right and responsibilities.

The model result has shown that, information access has positive effect on dependent variable i.e. economic empowerment of rural women with $\left(_{\beta}=2.427\right)$ and statistically significant at $1 \%$. This finding is consistent with results of studies done by Margaret (2015) and Zhera (2014) that dictates access of information significantly influences the economic empowerment of women in agricultural activities. According to Mikinay (2008) and 
Kaba (2009), farmers' decision is influenced by access to information which supports this result.

Participating on community affairs (PCMNITYAFRS) Women communal Participation is an important ingredient to enhance their economic empowerment in rural agricultural activities. Consequently, it increases their interactions and exposure to the external community and interventions as well. Therefore, it was hypothesized that women, who have better participation in different communal activities, will have a better Economic empowerment. The result of the Binary logit regression model confirms that there is a significant and positive relationship between women's community participation and their economic empowerment in rural agricultural activities with $\left({ }_{\beta}=1.051\right)$ and statistically significant at $1 \%$.

The marginal effect of the model showed that, as participation of rural women increases by additional one year on average the probability of women to become economically empowered increases by $26 \%$ marginal change, keeping other things constant. This finding is consistent with results of studies done by Mengistie (2013) and Zhera (2014). Therefore, the researcher can conclude that, as the community participation of women increases, the probability of being economically empowered will also increases in study area.

Distance from market (DSTNCFRMMKT): As expected, this variable was negatively associated with economic empowerment of rural women and statistically significant at $10 \%$ probability level $(\beta=0.396)$ and statistically significant at $10 \%$. The marginal effect of the model result reveals that women having longer distance from the market center are less likely to be economically empowered than those who nearer to market Centre by $9.75 \%$. But the result of this finding is inconsistent with the results of Zhera (2014) which illustrates that there is no definite conclusion can be drawn about the relationship between distance from market center and economic empowerment of women.

\section{Summary}

The summary of the findings were made based on the objectives and research questions which the study sought to address. The objective of this study is to investigate the determinants of economic empowerment of rural women in agricultural activities in Damot Gale Woreda. In order to address the research objectives, both quantitative and qualitative approach were employed. The researcher totally distributed three hundred seventy four questionnaires to the sampled Kebeles in the Woreda to collect primary data. Out of three hundred seventy four questionnaires (374) distributed, finally three hundred sixty nine (369) questionnaires were correctly filled and returned back. i.e., the response rate of the research was (98.6 percent) and in addition to this the Focus group Discussions (FGDs) and key informant interviews were used as an instrument to collect information from different Institutions in the area.

Secondary data were collected from different publications and unpublished materials. After the data collection was completed, the qualitative data that have been collected through questionnaire were coded to be quantitative data and entered into the computer to be analyzed using SPSS version 23.0, 16.0 \& STATA 13. Qualitative data collected through interview and focused group discussion were analyzed through narration by linking with each variables incorporated in the model to clarify the findings of this study.

\section{Summary of Inferential Statistics Result}

As it can be seen in the Table: 4.3 the researcher tested whether the fourteen explanatory variables such as age, family size, education status, spousal relationship, farm size, household farm income, non/off-farm income, employment/doing on paid job, ownership of property, credit utilization, extension service, access of information, participation of community affairs and distance from the market were incorporated in the model and hypothesized to affect economic empowerment of respondents in the study area. Out of these, eleven variables such as age, family size, education status, household farm income, off-farm income, employment/doing any paid job, ownership of property, credit utilization, access of information, distance from the market center, and participation of community affairs were statistically significant But it was displayed that the remaining three variables i.e. spousal relationship, farm size and extension service not significant in the study area.

Accordingly, when it summarized the statistical significance of each variable as follows:

$>$ When it comes to the influence of independent variables on dependent variable, age of the respondents as one of factor affecting economic empowerment of rural women is significant at $1 \%$ confidence level since p-value $0.010 \leq 0.01$ and positively associated with dependent variable because its $(\beta=0.464)$ followed by education status of rural women with $(\beta=0.346)$ at $5 \%$ since $p$-value 0.011 .

$>$ Concerning other explanatory variables including household size, employment/doing any paid work, distance from the market center and credit utilization have negative influence on women economic empowerment having $[\beta=-0.624,-1.183,-0.39$ and -2.890 respectively were statistically significant at $1 \%$ because their $p$-values were less than $1 \%$. With regarding to other explanatory variables like household income, non-farm income, ownership of property, access to information, and participation on community affairs have positive influence on women economic empowerment having $[\beta=1.748,1.242,1.385,2.427$ and 1.051 ] respectively were statistically significant at $1 \%$ because their $p$ values were less than or equals 
to $1 \%$. In contrary, variables such as spousal relationship, farm size and extension service access of the respondents haven't significant influence on economic empowerment of rural women.

\section{Conclusions}

Conclusion is the process of making generalization based on findings of sample to total population. Therefore, the findings revealed from this study were generalized to all rural women in the Woreda as follows;

The conclusion is made for both statistically significant and insignificant variables as through binary logistic regression model as follows:

WEAI score indicated that women farmers were empowered in $74 \%$ of the $5 \mathrm{DE}$ indicator (see Table: 4.2 ). Among the 5DE contribution of each indicator to disempowerment, Inadequate group membership, lack of adequate Purchase, sale and transfer of assets and control over income obtained from credit, inadequate public speaking, and lack of relative autonomy in production contributed most to women's disempowerment.

The result of logistic regression indicated that out of fourteen independent variables incorporated in the model, eleven variables such as age of respondents, household size, education status, household income, non/off-farm income, employment/doing any paid work, owning property, credit utilization, distance from the market center, access to information and participation on community affairs were found to be the determinants of women economic empowerment in the study area.

Consequently, Investing in rural women's economic empowerment in agricultural activities is crucial for gender equality, poverty eradication, human development and inclusive economic growth, yet significant gendered inequalities persist globally. Overcoming these inequalities requires bold, wide-ranging and transformative approaches. It has drawn on the wide body of evidence available to identify 11 key factors that enable or constrain women's economic empowerment, and provided policy recommendations for each.

\section{Recommendations}

Recognition of women's role and contribution to social and economic development in general and that of agricultural development in particular by planners and decision makers would help to enhance the status of women and increase food security and economic change at household and national level.

As per the Constitution of FDRE, women's right must be respected by avoiding the social bias (cultural influence) at woreda level. This requires the involvement of leaders, politician, planners and decision makers, development partners and donor agencies in the study area. Consequently, Addressing the constraints to implementing the national policy on women, the woreda make strategies to enable supporting the grass roots women's organizations that will build women's ability to organize themselves to effectively voice their concerns and preferences about their economic, social and civil rights. That is why the researcher recommends the Woreda decision makers should expand their policy and structures that were intended to promote and support women's empowerment in all sectors.

Since the contribution of women in reducing poverty and hunger is more important, the Woreda concerned bodies essentially promote to empower women status for making decision on all economic and income generating activities. As the result based on the findings of the study, it is recommended that Damot Gale Woreda concerned Authority has to work on the following areas in order to increase the economic empowerment of rural women in agricultural activities.

* It is better, if the Damot Gale Woreda Women Affairs works on training young females about economic empowerment and its importance that it has to them in particular and the society as the whole. Because the study demonstrates the older women have more economically empowered than the younger one. So that educating and training in the way they can positively understand about economic empowerment of women may be best alternative to improve the empowerment of younger generation since the majority of economic activity was on their hands.

* It is better and constructive if women affairs work on improvement of organizational efficiency in aspects of service delivering, family planning and awareness creation. Because the study shows that the family size (household size) has negative influence on economic empowerment of rural women. This implies that rural women are not satisfied with women affairs performance. In order to bring organizational strength in to effect, it should work on providing good public service, bringing good reputation in awareness creation, carefully training of family planning rules in the study area.

* About the education status of rural women, the study shows there is a positive association between economic empowerment and education level of respondents, this may be due fact that education improves the attitudes and self-confidence of women. Hence, to enhance the economic empowerment of rural women, the society should give priority to rural daughters in particular and educate rural women as whole in general. The Ministry of Education and the Ministry of Women \& Children's Affairs should implement education programs for rural women more effectively.

* It would be a good measure for women affairs office to reduce unemployment rate through job creation. 
To this end this study shows employed/doing any paid worker women have more economically empowered than unemployed one. Consequently to improve employment rate, the concerned body should give extended consultative session with elderly, rural women representatives, clan and religious leaders and other individuals that have high respect from society to influence the overall society to have positive attitude by reducing negative attitude towards rural women economic empowerment and their work in general.

* In the aspect of household farm income, even if the current study shows positive relationship between income and economic empowerment, it is better if the concerned body again gives trainings on how rural women farmers more improve their income level and their livelihoods through agriculture. That is they need to widen the provision of basic inputs like fertilizer, selective seeds, and implements to increase their income.

* Micro finance institutions of the region, Damot Gale sub-branch should also to work on credit utilization to facilitate and accessible for rural women as much as possible. This study find out lack of credit utilization has negative and significant influence on rural women economic empowerment in the study area. Ensuring the access of loan from financial institutions enables unemployed women to create their own business activity due credits extended from financial institutions. The Woreda finance officers collaboration with political leaders and decision makers should facilitate financial services such as microfinancial institution access and utilization to disadvantaged rural women to enhance their ability of generating income to ensure the well-being of their families.

* Additionally, ownership of the property has positive and significant influence on the economic empowerment of the rural women. This finding supports that accumulating wealth which belongs to women is very crucial to be economically empowered for rural women. Hence, women should create wealth by participating in more productive activities and it is better to have advice and awareness for society to inherit the property for women from their parents to enhance wealth accumulation in the hands of their own.

* Moreover, as non-farm income and economic empowerment have found to positive and significant in current study. Accordingly, the Damot Gale woreda can expand more consistent and regular nonfarm/off-farm activities, training the rural women of the area about job creation with respective support and increase income from that activity.

* Besides, the woreda in essence make the access to information better as much as possible by keeping in mind the cost related getting information by the women. Because the result of this study demonstrated that access to information is positively related to the economic empowerment. There need to have advice and awareness creation on essence of information access to rural women.

* Participation in community affairs as one of the factors affecting women economic empowerment has positive association with empowerment. It is obvious that participating in all social affairs for every one is the way to have good relationship in the society, well informed about job opportunities, obtaining guidance about what is good and bad in daily life aspect and sharing the way economically better family achieved their goal of wealth creation to follow their footsteps. Consequently there need to have mandatory request of the women to take part in any social meeting separately as well as jointly with men.

* WEAI score indicated that women farmers were empowered in $74 \%$ of the 5DE indicator. Therefore, greater effort is needed to empowering women in different aspects. The improvement of the contribution of each indicator to women disempowerment according to their importance shall reduce disempowerment and facilitate adequate empowerment in all dimensions.

\section{Directions for Further Research}

Since any study cannot be free from limitations, there is consideration of some limits in current study. Originally, it focused only on determinants of women economic empowerment at rural area in Damot Gale Woreda. Consequently, the findings of this study may be difficult to generalize about all rural women at national and regional level.

* Hence, this study can be further improved if it is done at regional and national level by comparing economic empowerment of different areas by changing sampling to other categories of rural women in different economic sectors.

* Further researchers can also include other determinants of economic empowerment of rural women in agricultural activities that were not included in this study since current study analyzed fourteen factors on the same area, at national and regional level.

* Another possible research topic that can be investigated is why the three variables such as spousal relationship, extension service and farm size of rural women incorporated in the model have not significantly affecting the economic empowerment in the same area.

* Finally, other researchers can also make comparative study among rural and urban as well as marred and 
unmarried women in current study area or else.

\section{Acknowledgments}

I am very honorable to appreciate the sponsor of this study, Dilla University, which is one the first generation Universities in Ethiopia that striving to serve the community and supporting problem solving researches thoroughly. My pleasant thanks also goes to the women and child affairs officers and rural women of Damot Gale woreda for providing information that is valuable for success of this study. The author also would like to thanks the editor and the anonymous reviewers for their guidance in developing this manuscript.

\section{References}

Aazami, and Karim Naderi Mahdei, 2011. Socio-economic Factors Affecting Rural Women Participation in Productive Cooperations: Case study of Paveh Ballmaking Cooperative. Iran. African Journal of Agricultural Research, 6(14), pp. 3369-3381, 18 July, 2011. (Available online at http://www.academicjournals.org).

Abebe Getahun, 2011. Women Participation in Rural Cooperatives: The Case of Bure Woreda, West Gojjam Zone, Amhara National Regional State. M.Sc. Thesis Presented to the School of Graduate Studies of Haramaya University, Ethiopia.

Adekunle OO (2013). Analysis of effectiveness of agricultural extension service in among rural women: a case study of Odeda local government, Ogun State, Nigeria Ogundiran

Oluwasola Adekunle. International Journal of Science, Technology and Society. 1(1): 36-42.

Afroz, Maksuda (2010). Effect of organizational governance on women's participation in decision making, Master in Public Policy and Governance Program, Department of General and Continuing Education, Bangladesh: North South University.

Ahmed Mohamed (2013). Microfinance and Rural Women's Empowerment: A Cross-Sectional level Analysis (Evidence from Rural Woreda's of Harari Region) Master Thesis Mekele University, Mekelle, Ethiopia.

Alkire, S., Meinzen-Dick, R., Peterman, A., Quisumbing, A. R., Seymour, G. and A. Vaz, 2012. The Women's Empowerment in Agriculture Index," Poverty, Health \& Nutrition Division, International Food Policy Research Institute, IFPRI Discussion Paper No. 01240, 2012.

Almaz Giziew, 2008. Adoption of Chickpea Technology Package in Ada'a and Akaki Woredas, Eastern Shewa, Ethiopia M.Sc. Thesis, Presented to the School of Graduate Studies of Haramaya University.

Amanuel Disassa Abshoko, Nigatu Degu Terye, Aklilu Toma Shamenna. Determinants of Socio- economic Empowerment of Married Women: Evidence from Ethiopia. Humanities and Social Sciences. Vol. 4, No. 3, 2016, pp. 66-75. doi: 10.11648/j.hss.20160403.11

Anaeto F.C., Asiabaka C.C., Nnadi F.N, Ajaero J.O., Aja O.O., Ugwoke F.O, Ukpongson M.U, and Onweagba A.E. (2012). The role of extension officers and extension services in the development of agriculture in Nigeria. Journal of Agricultural Research Vol.1 (6), pp. 180 - 185.

Anila Afzal, 2009. Identification and Analysis of Factors Hampering Women Empowerment' in Agricultural Decision Making and Extension Work in the Punjab, Pakistan: A case Study of District Okara

Aregu Asmare, Aster Ketema and Mesert Taddesse (2017). The Impact of microfinance on Women's Empowerment in Bench Maji Zone. Double-Blind Peer Reviewed Refereed Open Access International Journal and ISSN: 2249-0558 Impact Factor: 7.119 Vol. 7.

Asres Elias., 2005. Access and Utilization of Development Communication by Rural Women in Dire Dawa Administrative Council, Eastern Ethiopia. Unpublished M.Sc. Thesis presented to the School of Graduate Studies of Haramaya University, Ethiopia.

Ayevbuomwan O.S, Popoola O.A \& Adeoti A.I (2016). Analysis of Women Empowerment in Rural Nigeria: A Multidimensional Approach. Global Journals Inc. (USA) and Online ISSN: 2249-460x \& Print ISSN: $0975-$ $587 \mathrm{X}$.

Bureau of Finance and Economic Development (BOFED), (2017), "Demographic and Socio- economic profile of SNNPR", Hawassa.

Bureau of Finance and Economic Development of Wolaita Zone (BOFED), (2017) socio economic document. unpublished Wolaita Sodo (Amharic version).

Chalchissa, Amentie \& Emnet, Negash 2013. Women's involvement as an effective management tool in decisionmaking in Oromia region's public organizations: Full Length Research Paper, College of Business and Economics, Department of Management, Jimma University.

CSA (Central Statistical Agency), 2014/15. National statistics population survey, Addis Ababa, Ethiopia.

Damisa M.A. and Yohana.M., 2007. Role of Rural Women in Farm Management Decision Making Process: Ordered Probit Analysis. World Journal of Agricultural Sciences, 3(4): 543.

Damot Gale Woreda Finance and Economic Development Office (DGFEDO) (2017). Damot Gale Woreda Finance and Economic Development Office, Annual Report 2017. Bodditi, Ethiopia.

Damot Gale Woreda Finance and Economic Development Office (DGWFEDO) (2017). Physical and socio- 
economic profile of the Woreda.

Damot Gale Woreda Agricultural Development office (DGWADO) (2017), Agricultural development profile of the Woreda.

Desalegn Senbeta, 2008. Determinants of Famers' Participation in Micro Finance Institutions and Their Behavior in Savings. The Case of Toke Kutaye District, West Shewa Adminsrative Zone, Oromia Regional State. MSc Thesis. Haramaya University. 129p.

Diana Fletschner and Lisa Kenney, 2011. Rural Women's Access to Financial Services Credit, Savings and Insurance. Agricultural Development Economics Division. The Food and Agriculture Organization of the United Nations (WWW.fao.org/economic/esa).

EEA (Ethiopian Economic Association) and EEPRI (Ethiopian Economic Policy Research Institute), 2006. Evaluation of the Ethiopian Agricultural Extension with Particular Emphasis on the Participatory Demonstration and Training Extension System (PADETES). Addis Ababa, Ethiopia: EEA and EEPRI.

Green, W., (2003). Econometrics Analysis .Fifth ed. Printice Hall, peason Education, Inc.upper Saddle river , Newjersy. New York Univeristy

Haimanot Eshetu (2007). Impact of Micro-finance on women's economic Empowerment. A case-study of Amhara Credit and Saving Institution (ACSI), Kobo Woreda, Amhara National Regional State, Ethiopia. Master Thesis AAU. Addis Ababa, Ethiopia.

Hassan, R., and Nhemachena, C. 2007. Micro-Level Analysis of Farmers' Adaptation to Climate Change in Southern Africa, IFPRI Discussion Paper 00714, August 2007.

Hosmer D.W. and S. Lemeshow (2013) Applied Logistic Regression, 3rd Edition. New York: Wiley.

Huria A.M. (2014). An Assessment of Women Farmers' Participation in Agricultural Extension Services for Income and Nutrition Improvement in Ethiopia: The Case of Becho District, South West Oromia. Master Thesis AAU. Addis Ababa, Ethiopia.

IFAD (International Fund for Agricultural Development), 2011. Enabling Rural Women's Economic Empowerment: Institutions, Opportunities and Participation, Accra, Ghana.

IFPRI (International Food Policy Research Institute), 2010. Accelerating Ethiopian Agriculture Development for Growth, Food Security, and Equity.

Imran Sharif Chaudhry and Farhana Nosheen, (2009), 'the Determinants of Women Empowerment in Southern Punjab (Pakistan) "e: An Empirical Analysis, European Journal of Social Sciences - Volume 10, Number 2

Israel G., 1992. sampling the evidence of extension program impact, Program evaluation and organizational Development', Institution of Food and Agricultural science (IFAS)..

Jemal Kuru, 2010. Access and Utilization of Agricultural Knowledge and Information by Women Dairy Farmers: the case of Ada'a District, Oromia Regional State, Ethiopia M.Sc. Thesis, Presented to the School of Graduate Studies of Haramaya University.

Julia Wiklander (2010). Determinants of Women's Empowerment in Rural India. An Intra- Household Study.Master's Thesis Lunds University, India.

Kaba Merga, 2009. Analysis of the Gender Disparity in Agricultural Extension Service Delivery: the case of Gedeb Woreda, West Arsi Zone, Oromia Regional State. M.Sc. thesis, Presented to the School of Graduate Studies of Haramaya University.

Kanbiro Orkaido Deyganto (2018). Determinats of tax compliance attitude with taxation. A case of category "a" taxpayers in gedeo zone. Master Thesis DU. Dilla Ethiopia.

Kishor, S. and Subaiya, L. 2008. Understanding Women's Empowerment: A Comparative Analysis of Demographic and Health Surveys (DHS) Data. DHS Comparative Reports No. 20.

Lemlem Abebe, Dereje Kifle, Hugo De Groote (2016) Analysis of women empowerment in agricultural index: the case of Toke Kutaye District of Oromia, Ethiopia. Invited paper presented at the 5 th International Conference of the African Association of Agricultural Economists, September 23-26, 2016, Addis Ababa, Ethiopia.

Mahmud, S, Shah, NM, \& Becker, S, 2011, Measurement of women's empowerment in rural Bangladesh, World Development, vol. 40, no. 3, pp. 610-619.

Margaret Muthoni Njega (2015), Determinants of economic empowerment of women in Nyeri municipality, Nyeri, Kenya. International Journal of Economics, Commerce and Management United Kingdom Vol. III, Issue 10, October 2015.

Mariam Khalid (2014), Socio-economic Determinants of Women Empowerment: A Case Study of Cholistan Desert, Pakistan, Volume 5, ISSN 2229-5518

Maysoon abdel hameid abdelhai osman (2015). Analysis of factors influencing women's decision to Adapt to climate change: the case of rural women in Haramaya district, Eastern Ethiopia, Master Thesis Haramaya University, Haramaya, Ethiopia.

Mengistie Mossie (2013). Analysis of factors influencing rural women participation in performing household farm management practices: the case of Enebsiesarmidir District, East Gojjam Zone, Ethiopia. Master Thesis Haramaya University.Harar, Ethiopia. 
Messay Tegegne. 2012. An Assessment on the Role of Women in Agriculture in Ethiopia. Indira Gandhi National Open University, India.

Mikinay Hailemariam, 2008. Social Networks and Gender Dimensions in Use of Irrigation by Farmers in Alamata Woreda, Southern Tigray, Ethiopia.

MoA (Ministry of Agriculture), 2011. Guidelines for Gender Mainstreaming in Agricultural sector, Addis Ababa.

Mosedale, S. (2005). Assessing women's empowerment: Towards a conceptual framework. Journal of International Development, 17(2), 234-257.

Nazrul Islam, Ezaz Ahmed, Janet Chew and Brian D’Netto (2012). Determinants of Empowerment of Rural Women in Bangladesh World Journal of Management Vol. 4. No. 2. Pp. 36-56.

Ragasa, Guush Berhane, Fanaye Tadesse, and Alemayehu Seyoum Taffesse, 2012. Gender Differences in Access to Extension Services and Agricultural Productivity, Ethiopia.

Rajulton Fernando. (2011) Logit, Probit and Tobit: Models for Categorical and Limited Dependent Variables, Presented at PLCS/RDC Statistics and Data Series at Western March 23, 2011.

Rebecca AA (2012). Attitude of women farmers towards agricultural extension services in Ifelodun local government area, Osun State. American Journal of Social and Management Sciences. 2151-1559.

Roman Hirpo, 2010. Determinants of Rural Women Empowerment. The Case of Self Help Development Credit Services in Haramaya District, East Hararghe Zone, Ethiopia. MSc Thesis, Haramaya University.

Saunders M. Lewis P. and Thornhill A. (2009) Research Methods for Business Students $5^{\text {th }}$ Edition. FT Prentice Hall.

Shahnaj Parveen and Ingrid-Ute Leonhäuser. (2004) Empowerment of Rural Women in Bangladesh: A Household Level Analysis

Taye Chimdessa (2014). The impact of microfinance financial services on the economic empowerment of women: The case study of wisdom micro financing institution s.c, at woliso worda. Master thesis St. Mary's university. Addis Ababa, Ethiopia.

Vishal Goel (2015) Impact of microfinance services on Economic empowerment of Women: An empirical study Kaav International Journal of Economics, Commerce \& Business Management and ISSN: 2348-4969 Vol-2

WZFEDO (Wolaita Zone Finance and Economic Development Office) (2017). Physical and socio-economic profile of the zone.

WZADO (Wolaita Zone Agricultural Development Office) (2017). Agricultural development profile of the zone. WCYA 2013. Ethiopian Women's Development Package report.

Yamane Toru, (1967). Statistical introductory analysis, $2^{\text {nd }}$ edition Harper and Row Inc., New York. 345p.

Zhera Beyan (2014). Assessment of women empowerment through public agricultural extension services. The case of MeskanWoreda in the Southern Nations, Nationalities and peoples' region of Ethiopia. Master thesis, Haramaya University. Harar, Ethiopia. 